Vladimir Mau

Academy of National Economy of the Government of Russian Federation

Tel. + (7-095) 434-8389

mau@ane.ru

\title{
POST-COMMUNIST RUSSIA IN POST-INDUSTRIAL WORLD: ELEMENTS OF CATCHING-UP POLICY
}

Version of May 2003

The paper discusses the strategy of economic development of Russia, which has to be developed after the end of the first stage of post-communist transition - when private economy replaced the state-controlled one and stabilization has been obtained. Russia is considered as a heavy industrialized country, which has faced the challenges of post-industrial modernization in the logic of catching-up development. This makes it different from so called 'new industrial states' - countries that have to resolve the task of transformation of traditional (agrarian) society to industrial one. Analysis is based on the approaches of A.Gerschenkron to 'accelerated industrialisation' and their adjustment to post-industrial world. The author suggests a set of economic policy principles, which could ensure sustainable economic growth and stimulate structural reforms appropriate for the new challenges, that is to stimulate transformation of industrial country to post-industrial one. This is considered as a 'policy of catching-up post-industrialization'.

The author is grateful to Yegor Gaidar for discussion of the subject and comments on the paper.

Contents.

1. Introduction.

2. Catching-up development as a historical phenomenon.

3 . The complexities of analyzing the catching-up development in post-industrial world.

4. The state's role in addressing catching-up development

5. The outlines of post-industrial catching-up policy in post-communist Russia 


\section{Introduction.}

With the implementation of basic pro-market reforms and the conclusion of postCommunist transformation, the questions of the substance and nature of Russia's further development and the strategic goals of the its economic policy have been brought to the foreground. The elimination of the heritage of Communism per se cannot be regarded as a strategic target of national development. 'De-communisation' is just a prerequisite allowing to focus on strategic targets. While for the Central European countries these were quite obvious targets, namely, to become a part of the United Europe and to join the European (and Western, at large) institutions like EU, NATO, WTO and OECD, the key guidelines of Russia's transformation until recently have been issues of not only acrimonious debate, but also of fierce political confrontation.

During the 1980-90s Russia faced a systemic crisis in all spheres of social life economy, policy, and ideology. A number of interrelated though substantially dissimilar crisis processes were taking place in the country. Russia had experienced a prolonged macroeconomic crisis and a systemic transformation of Communist institutions into those of market democracy. The transformation processes took the form of a full-scale social revolution, i.e., were accompanied by the destruction of state institutions which, for a while, lost control over the situation in the country ${ }^{1}$.

However, important as these changes were, they only unveiled much deeper process which the country was facing with and which eventually led to its crisis. From the 1980s the Soviet Union encountered formidable challenges of the crisis of industrial society. The experience of Western countries from the 1970s onwards shows that the crossing of the threshold on the way from industrial to postindustrial society was accompanied by severe structural and macroeconomic crises. Thanks to the favorable conditions of world markets, the USSR could delay the beginning of structural adjustment, only to experience even a more painful adjustment when there was no longer any escaping it. The structural crisis of the Soviet economic system, at the height of which came a drastic decline of the then already Russian economy, resulted from the same processes, which had taken place in the Western countries two decades earlier. $^{2}$

High energy prices not only delayed the beginning of the structural adjustment of Soviet society, but also contributed to its destabilization. The USSR made an attempt at a breakthrough in order to keep abreast of the transformed West. But this technological spurt was not supported by the adjustment of institutions and only led to the collapse of the country.

\footnotetext{
${ }^{1}$ For details see: Gaidar E. (ed.). Russian Economy in 2001: Trends and Outlooks. M.: IET, 2002. P. 5-8.

${ }^{2}$ For details see: Bauman Z. A Post-Modern Revolution? In Frentzel-Zagorska, J. (ed.) From a One-Party State to Democracy: Transition in Eastern Europe. Amsterdam: Rodopi 1993; Rosser J.B., Rosser M.V. Schumpeterian Evolutionary Dynamics and the Collapse of Soviet-Block Socialism. In Review of Political Economy. 1997. Vol. 9. № 2
} 
The starting point of our analysis is an obvious thesis that in the last third of the twentieth century the USSR faced a crisis of the industrial system, and that postcommunist Russia has to advance in the direction of postindustrial society. Since there is a considerable technological and economic gap between Russia and the most advanced countries (measured by per capita GDP, or by labor productivity), we are faced with the urgent problem of bridging this gap, in other words, with the problem of catching-up development.

Therefore, at the turn of the twenty-first century Russia faced challenges similar to those it encountered at the turn of the twentieth century. But nowadays, unlike a century ago, it is not a question of catching-up industrialization ${ }^{3}$, but is that of the catching up postindustrial development. It is here that the long-term aim of the development of Russian society lies. And it is the reduction and bridging the gap dividing Russia from the most developed countries that becomes the ultimate goal of Russian élite.

To begin with, we have to restrict the subject of this paper to comparing the specificity of catching-up development of the industrial and postindustrial societies, though the term 'catching-up development' is not quite suitable. It does not describe precisely the nature of objectives to be reached by the country. Economic history testifies that what is needed to eliminate a lag and to create a new economic system is not to repeat all the stages of technological development of advanced countries, but to achieve a socioeconomic breakthrough based on assimilating and digesting the technological, social and organizational experience accumulated by the most developed nations. ${ }^{4}$ Strictly speaking, breakthrough strategy is a more exact term than catching-up. However, we do not intend to go into a discussion about terms, and will use conventional term, bearing in mind its inaccuracy.

\section{Catching-up development as a historical phenomenon}

Catching-up development makes sense only in the context of socioeconomic underdevelopment. Hence, at least a brief definition of the phenomenon is needed. The notion of underdevelopment makes sense only from historical perspective, and this is determined by at least three aspects.

First, social and economic underdevelopment may be applied only to the epoch of economic growth, i.e. from the eighteenth century on. Previous epochs may also be considered in terms of more and less advanced nations (states), but in a situation of fundamental stability and absence of any considerable technological changes over a long period of time (centuries), the problem of underdevelopment was tackled simply enough: a less advanced nation adopted the achievements of a more advanced nation. Conquests played an important role in this process, and it did not make much

\footnotetext{
${ }^{3}$ The literature on the subject of catching-up development is quite extensive, and there were periods in the twentieth century when the subject was of particular interest to researchers. However, up to now virtually all the studies have been devoted to industrialization problems of traditional (agrarian) societies.

${ }^{4}$ Perez C., Soete L. Catching-up in technology. In: Dosi G. et al. (eds.). Technical Change and Economic Theory. London and New York, Pinter, 1988.
} 
difference who was more advanced - the conqueror or the victim: the Romans had adopted a lot from the conquered Greece and then passed on their own culture to the Barbarians.

And it is quite a different mission when there is economic growth that changes life of virtually every next generation. In a situation like that, mere development is not enough for a catching-up country, it has to develop faster than an advanced one. Moreover, mere adoption and implementation of the achievements of the latter is not enough either it may only allow the country to keep the gap set; whereas, what is needed is to quest and find ways (institutions, mechanisms) unknown then to a more advanced country. Hence, the first rule of catching-up development is as follows: for a success, it is not enough just to follow in the footsteps of a more advanced country.

Secondly, the problem of underdevelopment arose only at a definite stage of growth, when the differentiation of industries had taken place and it became evident that the contribution of different industries to the economic (hence, political and military) life of a nation was uneven, which was not evident up to the nineteenth century. At least, to Adam Smith the problem of underdevelopment looked like a purely quantitative problem and not like a structural one. Smith did not attach special significance to industrial manufacture; to him the priority sector was agriculture. This is not surprising since at the eighteenth century there were the agrarian monarchies, which exemplified the most flourishing and strong states. This is why Smith recommended that any country pursue the economic policy that would ensure the development of sectors in which the international division of labor offered relative advantages. According to Smith, it was the most effective unveiling of the country's resources that served as the main prerequisite of its prosperity. Thus, these recommendations were, practically, devoid of the structural component and of any industry-related priorities ${ }^{5}$. Only in the nineteenth century was it demonstrated that the underdevelopment is to a great extent a structural problem, i.e., it implies indicating advanced industries at a given stage of economic development. Hence, the second conclusion is that catchingup development always implies deep structural reforms.

Thirdly, characteristics of the lag vary at different stages of technological development. Conceptions of advanced and backward industries change as society develops. An industry that was once a springboard for development may turn into an obstacle (the history of coal industry is a classical example). In this context it is worthwhile to discriminate between the conception of backwardness in industrial society - as compared with the traditional one, and in postindustrial - as compared with the industrial one. This is why it is possible and quite natural to consider not only the turning of a backward country into an advanced one, but also vice versa.

\footnotetext{
${ }^{5}$ This is a very important point for understanding of liberal doctrine of catching-up development. This approach would be heavily criticized in the nineteenth and the twentieth centuries as an attempt to impose backwardness and prevent industrialization of the underdeveloped countries. But these arguments in favour of industrialization cannot be attributed to the experience of the eighteenth century, when the domination of manufacturing in the national economy was not the source of political or military power and international influence.
} 
The lag of the country may be characterized by both quantitative and qualitative indicators taken in their interrelation. The most general quantitative indicators of socioeconomic development are, naturally, the average per capita GDP, its absolute level and rate of growth.

Per capita GDP is not just a quantitative indicator, but is a synthetic qualitative one. The level of per capita GDP reflects definite stage in national development, since kindred countries are characterized by commensurable levels of this indicator. One can single out several ranges of these indicators, each range corresponding to a definite stage of socioeconomic development such as: agrarian monarchy; industrial society with authoritarian tendencies in political life; and market democracy with postindustrial trends prevailing. Though there are exceptions, ${ }^{6}$ the analysis of historical statistics strongly suggests that, all other factors being equal, commensurable ranges of per capita GDP (with due regard for PPP) indicates the basic similarity of the corresponding socioeconomic and political structures. Here, we can easily distinguish three groups of countries with three different levels of the average per capita GDP (as measured by A.Maddison ${ }^{7}$ ): below $\$ 1,500$, from $\$ 2,000$ to $\$ 6,000$, and above $\$ 10,000$. What is more, in countries where the average per capita GDP is within the range of $\$ 1,300$ to $\$ 1,500$ and of $\$ 5,000$ to $\$ 6,000$, intensive transformation processes can often be observed.

Backwardness may by characterized by per capita GDP being at a much lower level than that of the most developed (advanced) countries. It means, that economic, social, and political development of a given country is much lower as compared with the advanced levels of the given epoch. There is a considerable dispersion within each of these levels (especially, within the upper one). However, the quantitative dispersion of indicators of countries belonging to the upper level does not unequivocally suppose the superiority of one country over another: in this case, reference to catching-up development makes sense mostly in terms of eliminating quantitative backwardness, and to a smaller extent, the qualitative (structural) one. Different changes and regrouping may occur within the same level, but they do not necessarily reflect significant qualitative variations. What counts is the medium-term commensurability of growth rates of such countries.

Another reason why the quantitative changes of the economic development indicators (GDP included) should not be turned into absolutes is that big structural changes may be accompanied by output decline. Output growth and even growth acceleration may also coincide with an incipient economic crisis. An example of this is what happened to the USSR in its later period: in the 1970s quantitative growth indicators, though not too high, seemed to be quite satisfactory against the stagflation in the West, and after the "speeding-up" policy was declared in 1985, the growth rate in 1987-1988 even rose slightly. ${ }^{8}$ However, while according to statistics the country lived in 'prosperity',

\footnotetext{
${ }^{6}$ For details about exceptions see: Huntington S. The Third Wave. Norman London: University of Oklahoma Press, 1991. P. 65.

${ }^{7}$ Maddison A. Monitoring the World Economy 1820-1992. Paris, OECD, 1995.

${ }^{8}$ Hanson Ph. From Stagnation to Catastroika: Commentaries on the Soviet Economy, 1983-1991. New York, Praeger, 1992.
} 
the actual qualitative lagging behind the West deepened and the systemic crisis of Soviet Communism intensified. ${ }^{9}$

Indicators specific to a given phase of the socioeconomic development may also be used to characterize processes (bridging or reducing the gap) taking place in a country. For instance, early industrialization can be characterized by a number of industrial enterprises, the number of their employees, and the use of machinery. In the epoch of mature industrial society the important indicators were: concentration of capital and labor, degree of saturation of the production with machines and mechanisms, the level of coal, cast iron, steel and cement production (absolute and per capita). As opposed to that, in early postindustrial society the high level of concentration of heavy industry, that the industrial epoch was so proud of, has become a heavy burden (both in economic and social terms), and indicators characterizing the development of high technologies, rates of production reequipment, the level of the social development (especially education and public health), and of the sphere of services, in general, come to the fore.

The term 'socioeconomic backwardness' being historically conditional, makes it necessary to apply a specific historical and economic approach when solving the problem of overcoming backwardness. There is a number of different types of growing economic systems and a therefore number types of catching-up development. One can indicate five types of developments and, accordingly, five groups of problems confronting governments.

First, the establishment of general prerequisites for economic growth and transition from a traditional economy to a growing one. Factors determining the beginning of industrialization processes also belong here.

Second, catching-up development at the age of industrialization. It concerns countries that embarked on the way of industrialization much later than the pioneer countries (England and Belgium) and were confronted with specific problems of bridging the development-level gap between them and the pioneer countries. Classical examples of such countries are Germany and Russia, and, to a certain extent, France and the USA.

Third, transition from industrial society to postindustrial. While the crisis of the industrial system is a well examined phenomenon, the problems of postindustrial development are still the object of studies mostly carried out by political scientists (to be exact, by futurologists), and to less extent by economists.

Forth, catching-up development of traditional (agrarian) societies when the world faces with postindustrial challenges. This is a phenomenon of countries emerging nowadays from traditional (agrarian) systems, lake South-East Asian nations - South Korea, Taiwan and others.

Fifth, catching-up development of an advance industrial country confronted with postindustrial challenges. There are very few examples of countries like this, and it is

\footnotetext{
${ }^{9}$ Quantitative growth without adequate structural changes is not a rare phenomenon. There are many examples of it - from the eighteenth-century France to Byelorussia of the 1990s.
} 
hard to refer to them as actual case studies. But post-communist Russia is one of them. Mature industrial societies mainly existed in countries with developed democracies, that were more receptive to technological challenges and in which crises of industrial systems took place more or less simultaneously. ${ }^{10}$ The Communist regime remained in the past, and, considering the dramatically increased pace of changes, even a two-decade slowdown resulted in a substantial gap between the postCommunist and the pioneer countries.

One can suggest a list of principles of catching-up policy common for different times and different countries. Although this list will be too general and vague, it is not worthless producing a starting point for further analysis. One of the earliest and adequate proposals of the common principles of catching-up policy was done by J.S.Mill. His approach if of special interest for our analysis because Russia was directly mentioned by him among the addressees of his recommendations. Mill offers three principles of catching-up development:

«First, a better government: more complete security of property; moderate taxes, and freedom from the arbitrary exaction under the name of taxes... Secondly, improvement of the public intelligence: the decay of usages or superstitions which interfere with the effective employment of industry; and the growth of mental activity, making people alive to new objects of desire. Thirdly, the introduction of foreign arts, which raise the returns derivable from additional capital, to a rate corresponding to the low strength of the desire of accumulation: and the importation of foreign capital, ... and by installing new ideas and breaking the chains of habit, if not by improving the actual conditions of the population, tends to create in them new wants, increased ambition, and greater thought for the future. These considerations apply more or less to all Asiatic populations, and to the less civilized and industrious parts of Europe, as Russia, Turkey, Spain, and Ireland» ${ }^{11}$.

\section{The complexities of analyzing the catching-up development in post-industrial world}

The analysis of the catching-up development, as applied to the postindustrial world, is complicated by a number of factors.

First. The postindustrial society is just emerging. Its main features may not have been fully exposed yet. It is even hard to state definitely to what extent today's society possesses postindustrial features. As for industrial capitalism, it was only at the beginning of the twentieth century, and not at the turn of the nineteenth century, when the new economic system was only forming, that sufficient knowledge of it was obtained, although the analysis of capitalism by T.R.Malthus, D.Ricardo, and K.Marx, had a considerable impact on economic analysis. To be sure, there are many studies dealing with the post-industrialism, but the very starting phase of the system imposes really rigid (and quite narrow!) limits for any generalization. ${ }^{12}$

\footnotetext{
${ }^{10}$ Simultaneity we refer to is rather conditional. Obviously, there is a gap between the USA, Germany, Great Britain and Scandinavia, on the one hand, and Southern Europe (Italy, Spain, Portugal and Greece), on the other.

${ }_{11}^{11}$ Mill J.S. The Principles of Political Economy. Vol. 1, ch. 13.

${ }^{12}$ The very fact that the new social set-up still does not have an established (positive) name shows that our knowledge about it is quite limited. It is given names contrasting
} 
Second. The situation is aggravated by the lack of any catching-up development experience in the postindustrial world. In other words, the very phenomenon that we intend to analyze does not still exist. All the most successful examples of catching-up development (including those of the last fifty years) had to do with a very different type of problems, with transformation of traditional societies into industrial ones. Moreover, according to the history of last decade, the industrialization spurt did not in the least guarantee their successful overcoming the challenges of the postindustrial epoch. In the early 1980s the fast growth in Japan and countries of South-East Asia was seriously impeded by the very limitations of the industrial model and by these countries' inability (at least for the time being) to transfer into the postindustrial dimension. It may be assumed that the rapidly progressing China is also going to face serious problems of the same kind in the future.

However, the analysis of the catching-up development must rest upon real extensive experience. A. Gerschenkron's works with the most comprehensive and convincing study of the catching-up industrialization ${ }^{13}$ could have only been written on the basis of the comparative analysis of actual cases from the economic history (mainly Russian and German). The majority of other books covering problems of the catching-up development from more general and universal points of view were written only after Gerschenkron's works had been published. ${ }^{14}$

Third. The very peculiarity of the postindustrial system (inasmuch as we know it now) entails additional analytical difficulties. Its most important feature is that the ambiguity of all the functional parameters of society, undoubtedly, tends to increase. Two properties of postindustrial society, which radically differentiate it from industrial one, are responsible for this. On the one hand, the growing dynamism of technological changes which results in a much closer economic and technological forecast-time horizon. On the other hand, we are dealing with a virtually limitless increase in demands and with dramatic extension of possibilities (both in terms of resources and technologies) to meet these demands. All this increases many-fold the scale of economy, and radically individualizes (even 'privatizes') it: both demands

the preceding system: postindustrial, post-economic. Though there are "positive" names like "information society" or "network society", they are still not broadly accepted.

${ }^{13}$ Gerschenkron A. Economic Backwardness in Historical Perspective: A Book of Essays. Cambridge, Mass., The Belknap Press of Harvard University Press, 1962; Gerschenkron A. Continuity in History and other Essays. Cambridge, Mass., The Belknap Press, 1968; Gerschenkron A. Europe in the Russian Mirror. Four Lectures in Economic History. Cambridge, Cambridge University Press, 1970.

${ }^{14}$ Abramovitz M. Thinking about Growth. Cambridge. Cambridge University Press, 1989; Dosi G. et al. (eds.). Technical Change and Economic Theory. London and New York. Pinter, 1988; Cooper C. and Kaplinsky R. (eds.). Technology and Development in the Third Industrial Revolution. London, Frank Cass, 1989; Shin J.-S. The Economics of the Latecomers: Catching-up, Technology Transfer and Institutions in Germany, Japan and South Korea. London and New York, Routledge, 1996. 
and technologies become more and more client-oriented, which results in the aforementioned growth of overall ambiguity. ${ }^{15}$

Dynamism cannot be attained with the government selecting industries as priority targets for support. And it is not that the intervention by government is ineffective in principle, but that the very philosophy of the functioning of the economic system has to be changed. While in the industrial epoch it was possible to outline industrial priorities for 30-50 years ahead and to join the ranks of developed nations after attaining the goals (which was the case with Germany and, later, with Japan and the USSR), nowadays the priorities change very fast. For instance, a government might try to surpass the entire world in the number of computers per capita, or to plan the production of world's best airplanes and telephones, and on achieving it, only to find out that the world had gone far ahead. And what is more, it had gone in the direction nobody even thought about at the time when the program of universal computerization was being developed. Therefore, what the forthcoming postindustrial epoch requires is not "boxes" (be it even trite high-tech as such) but information flows. According to F. Hayek, the abuse of the infamous strategic planning on the part of the government is a "fatal conceit" and may only result in preserving the lag ${ }^{16}$.

Thus, singling out areas in which a country has relative advantages becomes an issue of much more importance that it was in the situation of industrialization. Here again, as it was at the early stages of "modern economic growth" (if one use the Kuznets" meaning of this word $^{17}$ ), we must give up targeting preset and predetermined breakthrough sectors (including the traditional industrial policies based on 'picking winners' or 'backing national champions ${ }^{18}$ ) and focus on revealing factors which would be most significant for the given country in the given circumstances.

Individualization determines the importance of decentralization. While a very important factor of industrial society was the economy of scale, its role in the postindustrial world progressively decreases. Obviously, where there is mass standard production there is also the scale effect, and big centralized corporations retain their importance. However, as science and its practical application in economic and social life come to the foreground, the possibilities of the scale effect and the positive impact of centralization become less. The collapse of the Soviet regime was, to a large extent, due to the fact that the system based on centralized decision-making proved to be basically incapable of solving the problem of "turning science into an immediate

15 According to some assessments, present-day mass-production in developed countries is responsible for only up to one third of the total production, while the rest is a customer-targeted small-batch production (from 10 to 2,000 items) with a much shorter manufacturing cycle." Khoros V. Postindustrializm - ispytanie na prochnost, in Globalnoe soobshchestvo: novaya sistema koordinat. S.-Peterburg: Alteia, 2000, p. 170.

16 Hayek F.A. The Fatal Conceit: The Errors of Socialism. Chicago, Il: The University of Chicago Press, 1990.

${ }^{17}$ Kuznets S. Modern Economic Growth. Rate, Structure, and Spread. New Haven and London: Yale University Press, 1966.

${ }^{18}$ Plender J. Labour's enduring love for gong-ho business, In The Financial Times. 2002. March 11, p. 26. 
productive force", though this motto was constantly repeated at all the CPSU congresses beginning with the 1970 s. $^{19}$

However, the difficulties and restrictions imposed by the present state of knowledge (or rather, by lack of knowledge) on the nature of postindustrial society should not serve as a pretext for not examining it, or for presuming that the government is essentially unable to pursue any comprehensible catching-up growth policy. We would only like to point out that today, when new economic and technological relations are just being established, economists and politicians must be extremely careful when handling their own conceptions and issuing recommendations.

Strictly speaking ambiguity is a natural element of economic development, and this is especially true about the period of radical structural reforms. Recommendations of the advanced nations to the less developed countries concerning transformation of their economic structure has been often rather ineffective and unreliable. As generals usually prepare to the past wars, economists often base there recommendation on the successful experience of the past. Although the following is an example dates back to the fifteenth century it seems to be important for the understanding of the problems in the modern world. An Italian visitor who came England in 1497 (one of the poorest European countries at that time) wrote: "The farmers are so lazy and slow that they do not bother to sow more wheat than is necessary for their own consumption. They prefer to let the ground be transformed into pasture for the use of the sheep that they breed in large numbers" ${ }^{\prime 2}$. Recommendations based on the existing experience made it clear that for the improvement economic situation England had to follow the practice of the most developed European nations and make a structural reform: shift from sheep-breeding to wheat production - but the lazy farmers did not want to do this shift. And only a few centuries later it became clear that this 'laziness' of English farmers created on of the most important prerequisites, which launched industrial revolution and then transformed Britain in one of the strongest nations in the world. In other words, nobody knows and nobody can know which vices or which virtue of nation will determine economic success or will end up with the national catastrophe.

${ }^{19}$ Prophetic are today the following words written in Soviet times, in the middle of the 1960 s by A. Lerner, expert in cybernetics: "A centrally-directed system is characterized by a structure of great rigidity and by lack of flexibility, since its adjustment to changes, both casual (fluctuations) and reflecting the evolution of the system proper and of its environment, takes place only in its management center and not in its separate parts. It is possible, through centralized control, to keep the system stable for a long time suppressing both the fluctuations and the evolutionary changes in its parts without rebuilding it. But eventually, it may be fatal for the system since the contradictions between the unchangeable structure and the evolutionary changes become so great and demand such a radical and drastic reconstruction, which is now impossible within the framework of the given structure, that it causes its destruction (that is, transition to a qualitatively new structure)." Lerner A. Nachala kibernetiki (Principles of cybernetics). M. : Nauka, 1967, p. 287.

${ }^{20}$ Cit. in: Coleman D.C. The Economy of England. London, Oxford, New York: Oxford University Press, 1977. P. 32 
Perhaps, there is only one thing we may be certain about: our present speculations and calculations, however well-grounded they seem to us today, will eventually (after postindustrial society reaches the state of maturity) appear to be quite naive.

\section{The state's role in addressing catching-up development}

All aforementioned factors and limitations considered, we will try to outline a practical policy that would secure the implementation of catching-up development.

Catching-up policy implies specific functions performed by the government which make it possible to bridge the gap separating the nation from more advanced countries. The role of the state has always generated heated discussions far beyond the range of theoretical polemics, it has always been a reflection of the political struggle going on in any society, which is aware of its backwardness and does not want to put up with it. The basic reference points (methodology principles) for research on this problem may be found in Gerschenkron's studies. Obviously, these reference points have to undergo a substantial transformation in order to be applicable to the development problems of modern society.

Gerschenkron singles out two aspects of activities of a state in a situation of catchingup society: the 'negative' one and the 'positive' one. ${ }^{21}$ While the former group of factors tends to develop a basis for structural transformation and accelerated growth, the latter consists of a set of socioeconomic conditions converting the potential of growth into actual growth.

According to Gerschenkron, the 'negative' role of the state means the removing obstacles to economic growth: creating a favorable environment, eliminating institutional limitations, securing political stability in the country. The detailed set of activities needed depends upon the circumstances of a country's historical development and the presence or lack of factors hampering economic growth. Quite often, the circumstances mentioned are the ones created earlier by the state itself. ${ }^{22}$

The 'positive' prerequisites include a package of special measures aimed at encouraging accelerated growth. These are just as diversified as the 'negative' ones, and in fact, appear to be certain institutions ensuring economic growth. These institutions differ from county to country and depend on the socioeconomic epoch the countries are going through: it could be investment banks (in Germany) or direct state participation in economic life (as was the case was in Russia at the end of the nineteenth and the beginning of the twentieth centuries). No one knows for sure what are these prerequisites and who successful they would work in a definite country.

To understand the state's role in various politico-economic circumstances it is essentially important to differentiate between 'positive' and 'negative' factors. The sets of measures, that are characterized as 'negative', taken in pioneer-countries well

${ }^{21}$ Gerschenkron A. Economic Backwardness in Historical Perspective, p. 19.

22 'Negative' prerequisites of growth include, for instance, agrarian reforms in Germany, or great reforms of Alexander II supplemented with the financial reforms of Alexander III. 
correlate with those taken in countries of catching-up development (provided the correlation is applied to the same stage of society's development and of its technological change). The state has to provide basic prerequisites for growth and to remove obstacles on the way of economic progress at the given stage of technological change.

The 'positive' role is quite another matter, and it was one of the most disputable questions in the history of economic policy. The general frame for the 'positive' role of the state was given in the abovementioned piece from Mill. Twentieth century contributed a lot to intellectual debate and practical implementation of this issue. According to Gerschenkron, it differs in various countries facing similar problems (for instance, related to industrialization). The role of the state as an economic agent in securing the growth of economy in industrialization-pioneer-countries was not significant; its role was rather limited during catching-up industrialization in Germany and Japan; and finally, the economic activity of the state was particularly important both for Russia/USSR in the first half of the twentieth century, and for the new industrial Asian countries after World War Two.

What does the state's significantly positive role in meeting the challenges of catchingup development depend upon? There may be two answers to this question. Gerschenkron, proceeding from the experience of industrialization alone, connects it with the level of backwardness of a country: the more backward the country is, the more important is the role of the direct intervention of the government in the economy. As the country is pulling out of backwardness, this interventionism would lessen and it may, for instance, give way to banks, as was the case in a relatively advanced Germany at the end of the nineteenth century. ${ }^{23}$ The other answer concerning the scope of the intervention has to do with the experience of the last decades of the twentieth century which makes it possible to assume that the role of the state depends upon the stage of socioeconomic development, differing substantially in industrial and postindustrial worlds. This point should be discussed in more detail.

The difference between the 'positive' role of the state in the industrial and postindustrial worlds is related, first and foremost, to the character of technology (productive forces, in Marxist terms) in either of the epochs. The qualitative difference between them, discussed in the previous chapter, predetermines different ways followed by the state authorities in achieving a technological breakthrough. In industrial society the state policy is focused on concentrating resources on the breakthrough technological changes, mobilizing all the available forces and facilities. In postindustrial society, with its fundamentally different level of technological ambiguity, this kind of policy is impossible and quite ineffective. Instead of concentrating resources, its main task is to secure the highest possible adjustment capacity of the entire society and of everyone of its economic agents, to create a political and legal environment encouraging them to reveal and satisfy to the full the interests and demands of their commercial partners.

Let's define the package of politico-economic conditions encouraging the achievement of catching-up development in postindustrial society. We are talking

\footnotetext{
${ }^{23}$ Gerschenkron A. Europe in the Russian Mirror, p. 123.
} 
about a certain package of positive aspects of the state's policy in the contemporary world.

Political regime. The first point to tackle is political stability and the appropriateness of the political regime to solve the problems of the particular country. The interdependence between social, economic, and political development has been thoroughly studied by economists and political observers. ${ }^{24}$ However, there should also be correlation between the level of economic development and the type of political regime most favorable for bridging the gap dividing that nation from more advanced countries. In other words, the problems to be addressed are related to the stage of the economic development, therefore, there must be a difference between political regimes fit for catching-up industrialization and for postindustrial development.

While the industrial breakthrough of backward countries required authoritarian regimes capable to concentrate forces and means on industrial priorities, the postindustrial breakthrough can be achieved only in a steady democratic environment. Researches show how and why the economic growth forms a general basis for strengthening political democracy and civil rights. ${ }^{25}$ However, an inverse relationship is no less important in a society based on information flows and individualization of requirements (demand): nowadays economic growth involves political prerequisites, namely, institutions ensuring freedom (political and intellectual) and private property (not only for tangibles, but rather for intellectual property as well).

Adjustment capacity of a society implies revealing creative forces of all the agents and can hardly be achieved if their initiative, both economic and political, is suppressed. Freedom of creative work, freedom of information flows and free admittance of individuals into these flows are major factors of a breakthrough. Paraphrasing a well-known Soviet-era cliché, one may say that freedom turns into an immediate productive force of society.

Another important political condition for any type of catching-up development is a consensus on basic principles and guidelines among the main interest groups and social strata, especially within the political, business and intellectual élite of the country.

Property rights. The establishment of a sound system of property rights is another basic problem of the catching-up development. As applied to postindustrial society, this should imply security private property as a prerequisite for the work of a creative

24 Huntington S. The Third Wave; Diamond L. 'Economic development and democracy reconsidered', in Marks G., Diamond L. (eds.) Reexamining Democracy. London: Sage, 1992; Barro R.J. Determinants of Economic Growth. Cambridge, Mass. and London, 1997; Vanhanen T. Prospects for Democracy: A Study of 172 Countries. London and New York, Routledge, 1997; Mau V. Ekonomicheskie reformy skvoz' prizmu konstitutsii i politiki (Economic Reforms through Constitution and Politics). M.: Ad Marginem, 1999.

${ }^{25}$ Kuznets S. Modern Economic Growth, p. 445-453; Huntington S. The Third Wave, p. 61-63. 
individual. This general provision should be implemented via specific aspects of property relations.

The most complicated problem here is maintaining and securing intellectual property rights. Quite popular is the idea that strict observance of intellectual property rights is one of the fundamentals of postindustrial breakthrough. Nevertheless, there are studies defending the opposite point of view: rapid growth in postindustrial world requires a maximal removing of restrictions imposed upon information traffic, hence, giving up intellectual property rights ${ }^{26}$.

It is rather a speculative discussion requiring further research and argumentation. Here we can only outline the problem but not resolve it. ${ }^{27}$ The best we can do is to assume that for postindustrial pioneer-countries protection of intellectual property rights was quite important (or even critical). But for catching-up postindustrial development simplicity and the highest possible availability of information resources (data on new phenomena and technologies) is of great importance. All the more so, since the useful life of new knowledge is short-run due to the acceleration of the technological change and of the spread of information.

Economic freedom. In postindustrial society political and economic freedoms are inseparable. Share of the budget in GDP may be taken as a statistical indicator fairly well reflecting the level of economic freedom. The assumption that to achieve highrate growth there has to be a rather low share of the budget in the economy (broad government budget amounting to about $20-25 \%$ of the GDP) is still a matter of discussion both in terms of degree of accuracy of its measuring and of the appropriateness of this indicator for dynamic analysis (does the rate of growth increase with the drop of the share of budget?). ${ }^{28}$ The analysis of the available (though quite limited) experience of postindustrial development makes it possible to draw only two conclusions as yet.

First, it seems that catching-up postindustrial development requires a smaller share of the budget compared with that of the pioneer-countries. In this respect it differs essentially from catching-up industrialization in which it was the catching-up countries that had higher levels of resources' concentration in their budgets. A smaller budgetary load corresponds with high ambiguity in terms of technology and economy: there must be relatively bigger resources at the disposal of private entities.

\footnotetext{
${ }^{26}$ Kinsella N.S. 'Against intellectual property', In Journal of Libertarian Studies, Vol. 15 , no. 2 (Spring 2001).

${ }^{27}$ Moreover, it is unlikely that it could be resolved theoretically without studying the case history of a successful catching-up postindustrial development, that in not available as yet.

${ }^{28}$ Illarionov A. 'Ekonomicheskaya svoboda I blagosostoyanie narodov' (Economic freedom and prosperity of nations), In Voprosy Ekonomiki, 2000, № 4; Mau V. 'Liberaliszm vserioz i nadolgo' (Liberalism now and forever), In Ekspert, 2000, № 11; Friedman L., Vidiasov M., Meliantsev V. Gosudarstmennse raskhody (potreblenie) $i$ ekonomicheskiy rost (Government consumption and economic growth). M.: NES, 1998.
} 
Second, the share of the budget in the economy besides a quantitative element also has a structural one. It is not the figures characterizing the scope of the state's intervention alone that count, but also how the resources are to be used. To illustrate, a more advanced educational system is a major factor of postindustrial development and requires appropriate expenses by the government.

Macroeconomic stability. This point was out of great importance in the industrial world. Moreover a number of countries of delayed industrialization based their catching-up strategy on the dismantling of macroeconomic (fiscal and monetary) stability. It was not an efficient strategy - none of those countries (beginning with the USSR) could launch a sustainable growth under high inflation and fiscal deficit. One can still see a position that a government overestimates the role of stabilization instead of institutional development (at least in post-communist world) ${ }^{29}$, but it is quite clear now from the practice of most of post-communist countries that economic growth resumes only after macroeconomic stabilization has obtained. Of course is important, but not sufficient factor for growth.

There are at least two reasons, why macroeconomic stability becomes even more important for catching-up countries in contemporary world. On the one hand, the diminishing role of direct intervention of the state in the economic life makes it necessary to have the efficient channels providing economic agents with the necessary information. (On the stage of industrialization government could regulate enterprises directly, by decrees, and these instruments offset to some extent the inefficiency of market information, while this information played marginal role). On the other hand, catching-up countries often have very poor 'credit records', which means low level of confidence of economic agents as the key players in market economy. Macroeconomic stability (and predictability) contributes to diminishing uncertainty and stimulation of investment activity.

Imports of institutions. Catching-up development implies establishment of a new institutional system. However, it is impossible to adopt, without any modification whatsoever, institutions that were used by pioneer-countries. While some of these institutions are 'universal', i.e., are indispensable for sustainable functioning of any developed society, others may not be capable of playing a positive role in bridging the gap in socioeconomic development. Sometimes an institution effective in an advanced society may prove to be an obstacle for the development of a backward country. Contrary, obsolete institutions may, at times, be used as a 'speeding-up' factor. Finally, not every institution thought to be capable of securing economic growth will fit into the new social or cultural environment.

Three type of institutions may be singled out: (1) institutions indispensable for sustainable functioning of contemporary economy; (2) institutions peculiar to a developed society, but hampering catching-up development; (3) institutions missing in advanced countries, but securing catching-up development. This classification is somewhat provisional, since at different stages of economic development and in different counties the impact of some institutions may be exactly the opposite. The most demonstrative examples of it are private property and competition which were

${ }^{29}$ One can find such and approach even in the papers of some outstanding economists such as J.Stiglitz (Whither Reforms? Washington D.C.: The World Bank, 1999). 
normally restricted during the catching-up development at the period of mature industrialism, while in postindustrial society securing private property and promoting competition prove to be important factors of progress.

It is important to notice that there is no standard set of institutional arrangements that can guarantee an economic success. The most important thing is not general rule, but the details and peculiarities, which cannot be replicated. As D.North noted, "economies that adopt the formal rules of another economy will have very different performance characteristics than the first economy because of different informal norms and enforcement..., ${ }^{30}$.

In relation to Russia at the time of its fast industrialization, Gerschenkron called attention to another peculiarity of establishing institutional prerequisites of catchingup development. He noted that there was a possibility of using old socioeconomic forms on having filled them with new content. This was a mechanism to stimulate modernization, to reconcile interests of the traditional forms and new challenges. As an example of such policy, he cites the role of Russian obshchina (community) as compared with analogous institutions in the countries with the early industrialization.

Comparing the policies pursued by of A.Turgot in France and Russian Finance Minister in the 1890-1900s S.Witte, Gerschenkron noted that while the former fiercely fought against the heritage of collective forms of business in villages, the latter used them in the interest of industrialization. The preservation of the obshchina in pre-Revolutionary Russia was indeed a matter of wonder and was quite often thought to be an important element of the county's cultural heritage, of the prevailing "community spirit". In fact, the obshchina being a tax-paying entity was quite an effective instrument in the hands of the government for re-allocating financial resources from the agrarian sector to the industrial one. ${ }^{31}$ This policy continued as Stalinist collectivization. Of course, the traditions of a bureaucratic state that was not accustomed to solving its financial problems through sophisticated institutions also had something to do with it. This idea is supported by the fact, that a similar institution - kolkhoz (collective farm) - was used by Stalin's USSR. ${ }^{32}$

Structural policy. Competition once again is becoming an important factor of economy. The use of specific (individual) business decisions by the government, i.e. direct intervention of the government in economy, has to be restricted, while the role of universal decisions has to be enhanced. First and foremost, the state must ensure the rights of economic agents to make decisions autonomously and to be responsible for their implementation. The state must enforce universal rules of economic behavior.

\footnotetext{
${ }^{30}$ North D.C. 'Economic performance through time', In American Economic Review, 1994. Vol. 84, no 3 (June).

${ }^{31}$ Gerschenkron A. Continuity in History and other Essays, p. 274.

32 It may be added that the use of old forms in new circumstances was not a very rare phenomenon in the economic history and was not so much and not only connected with the problems of catching-up development. For instance, it is well known that in the beginning of the seventeenth century early Stuarts tried to revive in England the institution of giving an oath to new sovereigns, regarding it as an additional source of funds independent from the Parliament.
} 
Particular danger appears to be specific business decisions concerning the accelerated growth of economy, when taken at early stages of policymaking. It is quite impossible, as of now, to define the actual comparative advantage of any given country. The chances that support (even moral support) of any sector will be harmful and will slow down the national economy are high, since in today's structure of economy the most influential and rich are, as a rule, traditional sectors which are unlikely to lead the breakthrough. But it is these sectors that have the most powerful lobbying potential and are able to impose their interests as national priorities on the whole country.

We do not mean to say that the most prosperous sectors now are by definition the source of patently ineffective policy-decisions. However, the easiest decision for them is to get political dividends in order to retain their favorable operational conditions as long as possible. The government may support their desires, which will result in preserving the present configuration and bringing down the structural adjustment potential of the economy. When the government stays away from direct support of specific industries and sectors, it will make them look for innovative approaches and new effective spheres for investments.

It should be reiterated that this implies giving up selection of industries and corporations as priority targets for support. However, such renouncing does not mean that no support must be rendered, say, to the export of other than primary commodities (products of engineering industry), i.e., to those who are able to pass an objective test of their competitiveness on the world market.

Giving up selecting industries as priority targets does not imply renouncing priorities when making politico-economic decisions (budgetary ones included). A large body of research evidence that investing in the human capital, specifically in education and public health, is of great significance. While being quite an important issue in the period of industrialization, its role today is, indeed, exceptional. Presumably, the ability of the government to concentrate resources for investing in education and public health is indispensable for speeding up postindustrial economic development. The state's participation here is all the more important because in a relatively backward country possibilities of private investments in education are fairly limited.

Concluding this chapter, I would emphasize three considerations of principle importance.

First, even if a government strictly follows all these (and others) recommendation of 'good conduct' it does not guarantee a success in achieving the desirable result. They form only general basis for success, but there is a number of other important elements of economic policy, relevant for particular country and in particular time. In other words, policy does matter, and general rules form only a set of basic prerequisites for catching-up strategy and they are never enough for this end. And the real problem is that these peculiarities of economic policy, which bring about the result needed for the country cannot be easily concluded from theoretical or historical considerations ${ }^{33}$.

${ }^{33}$ Even in the industrial world it was very difficult to elaborate 'common rules' for rapid economic development. One of the best examples is presented by a history of 
Secondly, in the postindustrial epoch the catching-up policy in some of its aspects resembles the policy of pioneer-countries of the early stages of economic growth. But nowadays the ambiguity of economic and technological progress is again rising dramatically. This explains the similarity of practical recommendations, which are focused on ensuring the adjustment capacity of private economic agents, on doing without excessive centralization, and on restricting direct intervention of the state in economy. However, in other respects the situation is very different from what it was in the sixteenth through eighteenth centuries: we are aware of the existence of ambiguity, whereas at the rise of industrialism it is unlikely there was anyone even suspecting such a phenomenon.

Thirdly, just as it was three hundred year ago, the adjustment potential of economy is much more significant than any of its quantitative indicators, thus placing important and quite specific demands on the political and economic arrangement of society endeavoring to bridge the gap dividing it from postindustrial world.

\section{The outlines of post-industrial catching-up policy in post-communist Russia}

Defining the problem facing Russia as catching-up postindustrial development we only establish a general approach for the strategy of a socioeconomic breakthrough. Still, it is a complicated problem. However, it can be realized in practice, provided the postindustrial breakthrough is ever achieved.

The first thing to be done for post-industrial development is broad liberalization of economic system inherited from communism. Liberalization was not only a part of post-communist transformation, but at the same time a first step of a new strategy - a strategy of post-industrial catching-up. That is liberalization was not the matter of desire of liberals, who formed the first post-communist government, but reflected the real demand of given phases of social and economic development - emergence of post-industrial world. Liberalization being very difficult task for implementation from political point of view technically (and intellectually) is a simplest act in this new strategy for economic and social transformation. Using Gerschenkron's definition, liberalization is a part of implementation of the 'negative' role of the state - quite obvious and more or less common for any country.

Liberalization was to be followed by macroeconomic stabilization, a bit more complicated act but also well known from the experience of many countries in the

industrialization of Russia and Spain in the nineteenth century. Both countries considered railroad construction as a central point of industrialization - a sector, which can stimulate (and accelerate) growth in other branches of national economy. But the results were substantially different. In Russia railroads in fact gave a great push to economic growth, contributed to establishment of many new enterprises. Spanish railroads also stimulated industrial growth, but... in France, because short distance and close connections between two countries made it more efficient for business to produce most of the necessary staff in the neighbour country. Of course in the beginning of the process of railroad construction no-one could predict these consequences - rather obvious at the end. 
twentieth century. Stabilization can be politically painful, but intellectually and institutionally it is not a big deal. All possible patterns and mechanisms of stabilization have been well studied and can be applied for any country mutates mutandis.

Liberalization and stabilization form the general basis for further development of the country, including the policy of post-industrial catching-up in Russia. But this already needs an original policy, which would become a result of intellectual analysis and practical efficiency of the nation and its élite. From this point the story of 'positive' role of the state begins, and the results of practical realization of this role are unpredictable. This makes the history interesting.

Let's discuss now the elements of this policy for contemporary Russia.

Growth models. Discussions on the preferable economic policy are centered round the role of the state, which is not only in line with the traditional Russian (and also Soviet) notion about the state's critical role in addressing large-scale politicoeconomic problems. It is also true conceptually: as was shown above, it is the state's role that is among the main factors in dealing with catching-up development.

There are four different approaches in addressing the problem of accelerated economic growth and in defining the state's role in the process.

First, typical for the left parties etatist model according to which the state is the main economic agent and it is only the state that can assume the responsibility for investing processes. It implies maximal concentration of financial resources (rents and export revenue) in the hands of the government and re-allocating them in accordance with 'national priorities'. No less significant in this model is protection of domestic producers against foreign companies. Thus, this model envisages an active 'industrial policy' in its conventional (sectoral) sense.

Second, enhancing the role of major conglomerates - financial and industrial groups (FIGs, or integrated business groups) in economic development of the country. Such agglomerations are believed to concentrate financial and intellectual resources for stimulation of economic activity and decrease transaction costs since financial, production and research institutions are amalgamated in the same conglomerate.

Third, an approach envisaging a drastic decrease of the share of the government in the economy, fitting it within the range characteristic of countries of the same level of economic development (bringing down central and local governments' budgets from $38-40 \%$ to $20-22 \%$ of GDP).

Fourth, economic growth based on encouraging enterprise activity, on creation by the government favorable conditions for investors, both Russian and foreign. It means the development of an adequate system of institutions, including legislation and lawenforcement policy.

The first two approaches can be jointly regarded as dirigiste, and the last two - as liberal ones. Though the two pairs are rather closely interrelated, their respective 
adherents are wrapped up in an active debate. Nowadays the most feasible approach seems to be a certain combination of the second, third and fourth models.

The FIGs are rapidly developing in post-commynist Russia. ${ }^{34}$ These groups can stimulate investment activity, and particularly in innovation projects. But there is also a risk of getting powerful and politically influential entities capable of imposing their interests on society as national ones. They also are keen to privatize profits and nationalize loses. Thus, the government's task is to make the most of their merits and neutralize their drawbacks. The latter is linked, first and foremost, with the necessity of intensifying to the efforts aimed at Russia's accession to the WTO (which counteracts domestic monopoly tendencies) and to strengthen the anti-trust policy.

The problem of lessening the share of the budget in the economy still has no definite solution. In 1999-2001 the share of the broad government in GDP had noticeably increased from 32 to 40 per cent. One could think this tendency is favorable for further lowering the tax burden. Anyway the real decrease of budget burden needs the reform of budget spending based on specially developed 'public expenditure review' (PER).

That is why the budget spending reform is now of great importance. The reform should be focused on two target areas. On the one hand, the maneuver needed to concentrate budget resources on sectors providing the normal working of political institutions conducive to minimizing transaction costs (state apparatus, judicial and law enforcement systems, the army), as well as human capital investment (first and foremost, in education, public health and science). On the other hand, from the macroeconomic point of view it is advisable to have a certain reduction of the share of government in GDP combined with the increase of the available volume of budget resources (which is quite natural under conditions of economic growth).

The strategy of establishing a system of institutions indispensable to catching-up development is a sensible one, though there is still a list of the vague questions. What kind of institutions are we talking about? From the political point of view, democratic institutions and principles, at least those guaranteed by the 1993 Constitutions of the $\mathrm{RF}$, must be maintained. In other words, we may talk about institutions characteristic of the most advanced countries of the world (taking into consideration the peculiarities of the post-revolutionary development of the country).

In terms of economics the situation is much more complicated. As of now, it is impossible to decide definitely to what extent institutions taken over from the pioneercountries will facilitate the catching-up development of Russia. To begin with, these institutions vary from country to country (compare the USA and EU). Second, a mere copying of their institutions, would imply adopting principles aimed at cutting down resources that would otherwise be used for addressing problems of catching-up development (first of all, it concerns the social sphere). However, adoption of some institutions would help Russia's integration with the most advanced counties (for instance, with EU) which would be an additional factor helping to reduce the gap.

\footnotetext{
${ }^{34}$ For details see: Dynkin A., Sokolov A. Integrirovannye bisness-gruppy - proryv $k$ modernizatsii strany (Integrated business-groups as a way to national modernization). M., 2001.
} 
The economic policy and business practice are yet to find answers to these problems. It can be assumed that Russia's institutional system may be built drawing on the EU experience, provided the share of the government in GDP is much lower. That would allow the country to make good use of some of the advantages of globalization and not to expose the economy to excessive bureaucratic (and social) pressure. However, this implies thorough examination of the institutional systems of the most advanced counties and picking out institutions appropriate for adoption by Russia, in terms of addressing the problems of catching-up development. It is quite obvious that only those institutions are acceptable for adoption that do not envisage the increase of the share of the budget in the economy and do not impose restrictions on innovative activities of private entities ${ }^{35}$.

Accepting that in reality problems of accelerated growth can only be addressed through a combination of approaches, including adoption of modern institutions together with restricting the actual government share in the economy and with making good use of the advantages of the integrated business groups, it must be stressed once more that it is quite dangerous to impose any industry-related priorities. Attempts of that kind are not infrequent today.

Another difficult problem is the establishment by the state measures effecting production conditions in a way to facilitate structural changes. It involves exchange rate and prices for services of the infrastructure (especially, energy-producing) industries.

The policy of gradual appreciation of the rouble, as well as imposing restrictions on the rise of tariffs, will support domestic producers in their struggle for customers. At the same time, it reproduces the artificial difference between the "rules of the game" used by domestic and foreign players and leads to preserving the present configuration and decreasing the incentives for innovations. The simplest way to resolve this contradiction would be gradual, as productivity rises, approximation of domestic and average world prices on energy (or rendering domestic prices comparable with the world ones). The situation, most likely, will be developing this way since there is an objective tendency of approximation of the national and world economic conditions, provided the Russian economy will be sufficiently open.

Indubitably, Russia's advantage is the high educational level of the population, especially as compared with the per capita GDP level. This factor is significant not only in terms of what was achieved during the past decades, but also because the population is clearly demonstrating a desire to invest considerable sums of money in this sector. Sociological surveys indicate that the Russians are ready to invest in education a great deal more than is normally done in countries of a much higher average per capita income level, let alone countries of the same income level. What we want to say is that the educational system must be under close control of the state,

\footnotetext{
${ }^{35}$ As it is easy to prove, a substantial part of EU legislation (acquis communautaire) have rather negative impact on economic growth and thus should be an impediment for catching-up growth. On the problems and contradictions of adaptation of EU legislation in Russia see: Maou V. Les relations Russie - UE: Problèmes et perspectives du développment. In : AGIR - Revue Générale de Stratégie. Stratégie russe pour le XXIe. Siècle. 2002. N 11-12.
} 
both in terms of budget spending and in terms of establishing modern institutions (including encouraging private investments in education). Improvement of this sector may soon become a cause consolidating national efforts.

No less important are investments in public health. It is a complicated sector of economy where both public and private investments may be effective. There are at least two reasons why this sector must develop fast. The first one is quite obvious: public health ensures the reproduction of the "human capital" which is a most important factor of postindustrial development. The other reason is that technologically this sphere of economy is closely interrelated with many high-tech sectors, hence investments in public health will generate demand in a whole chain of industries. What is more, it will not be an artificial demand as often is the case with state-defined priorities, but an actual demand of society. We can even say that public health may play the same role in postindustrial growth that was played by railroad construction in industrial growth in Russia in 1890-1900s.

Naturally, accentuating the role of the service sector does not mean forgetting about such other challenging sectors as automotive, ship-building, or aircraft industries. However, important as those sectors are (from political, technological and social points of view), they are unlikely to be the starting points of the breakthrough into the postindustrial dimension.

The openness of the Russian economy is an important factor in the transfer towards postindustrialism. The notion of openness being a factor counteracting monopoly tendencies and stimulus to innovation is only one of the aspects of the problem. It is the postindustrial breakthrough and not the notorious "protection of the domestic producers" that has to be pursued in the course of negotiations on WTO accession and subsequently on establishing a Common European economic area. Appropriate measures have to be aimed at entering world markets of promising industries and high-tech services rather than at protecting ineffective sectors. Such an approach radically changes our notion of what Russia needs WTO accession for ${ }^{36}$.

The strengthening of state institutions, though beyond the scope of economy as such, is also a priority issue in terms of transition to postindustrial society. The indispensable reforms in this sphere are as follows:

* reform of the judiciary system - more efficiency, more justice, more transparency in judgment, without which no steps to improve the economic legislation will be of any effect;

* reform of the system of governance (or administrative reform) - more efficiency and elimination of corruption in the state apparatus;

${ }^{36}$ The aforesaid is also true regarding the agrarian sector. Russian farming can be competitive on world markets (once the infrastructure is further upgraded). What is more, this sector of economy can form the basis for novel political initiatives: in the course of WTO accession talks Russia could initiate a radical rapprochement with the so called Cayenne Group (countries with a low level of protection of farming sectors, such as Australia and New Zealand). 
* military reform, first of all, a change of the conscription closely followed by a fast transition to contract recruiting to the army - we may just as well forget about the postindustrial breakthrough with the gifted youth wasting time and energy on draft evasion, and even going to foreign countries to study and work ${ }^{37}$.

With regard to the concepts of accelerated postindustrial growth it is not uncommon to hear suggestions of drafting a long-term program (or a strategic plan) of the socioeconomic development of the country. After a long period of deep transformation of society and politico-economic instability it is only natural that people turn to longterm projects. However, such documents must not be overestimated since the consequences may be quite negative. If such a paper is regarded as a kind of state development plan, it may throw the economic agents into confusion urging them to direct their efforts at state-defined priorities rather than at real challenges of productive forces and technological change, and it will be impossible to address the problems of catching-up development.

With the world entering the postindustrial epoch, the problem of specificity of catching-up development in these new circumstances comes to the forefront. What is more, Russia seems to be the first country to face this challenge. In any case, the problem of catching-up development is of indubitable interest to the Russian élite and, in general, to the major part of Russian society.

The question of to what extent it is actually possible to catch up will forever remain in abeyance. The study of socioeconomic development gaps between different countries in different epochs has more than once suggested the conclusion of an "everlasting lag". However, some countries have managed to solve this problem, though it should also be recognized that the past experience can not be translated unambiguously for the future: in general, the situation when the lag is insuperable, at least in the foreseeable future, can not be ruled out. Therefore, the ability to catch up has to be proved in practice again and again, and, of course, it is never possible to clearly predetermine what has to be done to address the challenges of catching-up development. We must be honest with ourselves and accept: today we cannot say about catching-up policy much more than what J.S.Mill has said a century and a half ago.

Of course, the system must be susceptible to mechanisms for achieving accelerated growth, but, as was justly noted by M.Abramovitz, "the trouble is that no one knows just what it means or how to measure it" ${ }^{38}$. One could consider various mechanisms for accelerated growth, or to formulate more or less precisely what must not be done, and what will impede economic growth. However, the actual economic breakthrough will be the result of the interaction of a great number of factors, of a very specific concatenation of circumstances, only ambiguously interpretable a priori. Therefore, the only thing we can be sure of is that it is only the future economic historians that

\footnotetext{
${ }^{37}$ Mau V. Pora spasat' Rossiyu ot armii (It's time to save Russia from its Army). In: Vedomosti. 2003, March 18.

${ }^{38}$ Abramovitz M. Thinking about Growth, p. 222.
} 
will definitely know and explain to everybody the trick of the economic breakthrough. 